\title{
LEGIBHITY
}

A major purpose of the Technical Information Center is to provide the broadest dissemination possible of information contained in DOE's Research and Development Reports to business, industry, the academic community, and federal, state and local governments.

Although a small portion of this report is not reproducible, it is being made available to expedite the availability of information on the research discussed herein. 
AUTHOR(S): S.A.W. GERSTL, ADAL

C.C. BOREL

SUBMITTED TO

PUBLICATION IN THE IGARSS '90 DIGEST

\title{
DISCLAIMER
}

\begin{abstract}
This report was prepared at an account of work sponsored by an agency of the United States Government. Neither the United States Grovernment nor any ajency thereof, nor any of their employecs. makes any warranty, expreas or implied, or anumes any leyel liability or responaj. bility for the accuracy. completenes, or usefulnew of any informat on, apparatus, produet, or prucese disclosed, or represents that its use would not infringe privately owned rights. Reference herein to any specific commercial product, proceas, or kervice by irade name, trademark, menufecturer, or otherwike does not nexessarily constitule of imply its endorsement, recommendation, or favoring by the Uniled Situtes Government or any agency thereof. The viewa and opinions of authors expressed herein do not necessurily state or reflect those of the United Staten Ciovernment or any axency thereof.
\end{abstract}

\section{MARCH 1990}

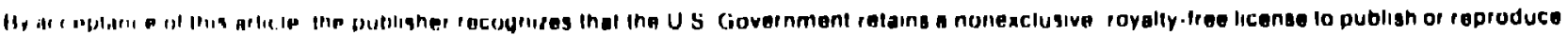

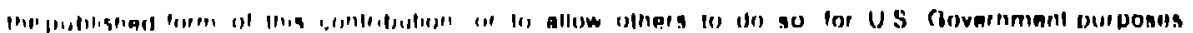

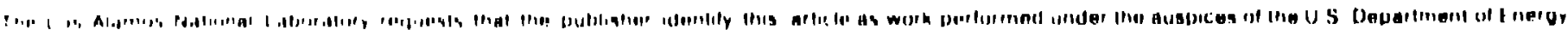

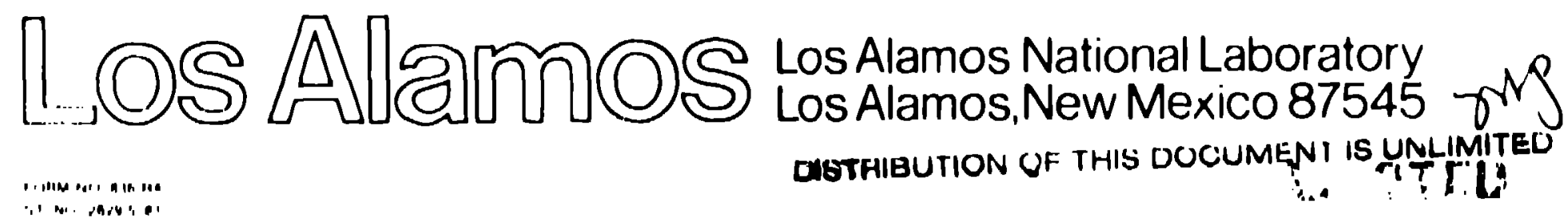


PRINCIPLES OF THE RNDIOSITY METHOD FOR CAKOFY REFLCTANCE MODELIKC

\author{
S.A.W. Gergel and C.C. Borel
}

Log Alomog National Laboratory

ADAL, A104, Los Alamos, MM 87545, USA

Tel. (505) 667-0952, FAX (505) 667.1754

\begin{abstract}
Abetract-The radlosity method $1 \mathrm{~s}$ incroduced to plant canopy reflectance modeling. We review the physics principles of the radiosity method which orlginaces In thermal radiative trangfer analyses when hot and cold surfaces are consldered ulthin a given enclosure. The radiosicy equation, which is an energy balance equation for discrete surfaces. Is dascrlbed and contrasied with the radlativo transfer equation, which is a volunetric energy balance equation. Compering the strengths and weiknesges of the rajlosity method and the ridlative transfer method, we conclude that both methods are complementary to each other. Results of sample calculations are gtven for canopy models $\because$ leh up to 20.000 discrete leaves.

keywords-canopy modeling. radiative transfer, rndlosity method, reflectance.
\end{abstract}

The classlcal approach to modeling the radiation fleld within vegetation canopy and at its boundarles in the rislble and near infrared reglme Is baged on the application of the radlative Iritifire (RT) equation (Ross, 1781) 14, whlch takes (live tistm

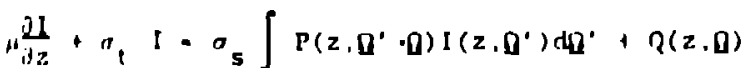

In ane-dimenslonal geometry, where we used senularel RT notation (c:f. F.B. liersil and inlerekl, |ros)'. The RT equation (1) replesents i halalice equation ror radlacive energy ior the mimber of photons) in an Influtesimal volume

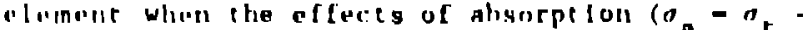
b) and scaterling (u) musc be cullalated. $f_{1}$

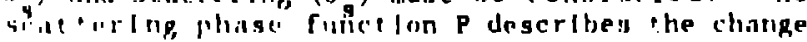

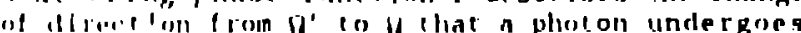
lil seisteling plocess, and the tern ls reprequnt.

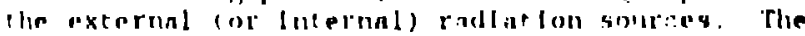
(a)lidion of Eid. (1) Is the lidlime illst rlbut lon

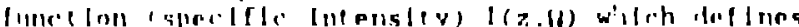

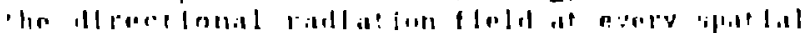

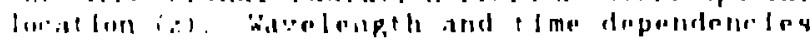

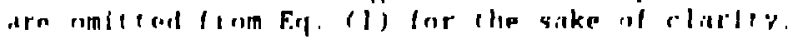

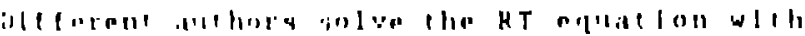

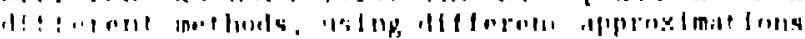

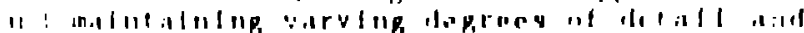

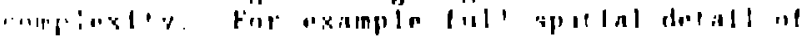

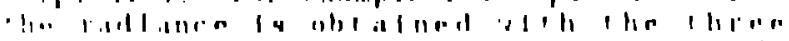

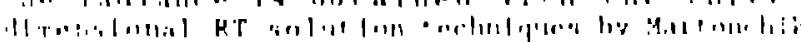

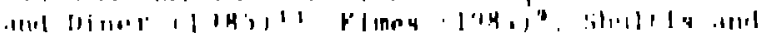

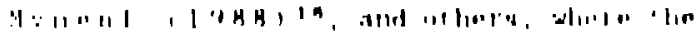

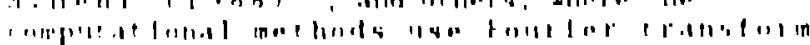

techniques, discrete-ordinates, finite-element. and brute-force numerlcal integracion techniques.

Desplte the breadth of applications, the Intrinslc l Imlcations of the problen description via the RT equation must not be overlooked. For example. in the RT Eq. (1) the radlatlve properties of a vegetation canopy are assumed to be complecoly descrlbed by the scatcering and absorption croso sectlons $a$ and $a(a-\sigma+a)$, or thel $r$ derlved quantities $r$ (optictel dêpth) and w (single scatcerting albedo), the scactering phase function $P$, and the boundary conditions. In order to deflne these quanclicles for a vegetation immpy. Le is necessary and stralght forward to rolute thim to measurable parameters Like the loaf aroa lindex (LAI), leaf angledIstribution (LAD), leaf hemlspherlcal reflectance $(p)$, trangmittance $(r)$, and absorptance (a), cf. . g. Gerstl a Zardecki $(1985)^{3}$. However, due to the nature of the RT equation ns an energy balance equation per yolume element, all measurablo canopy parameters must be averaged over such volume olements. Thls averaglng process eliminntos the discrete natile of lenves, stams, etc. from the mathomat ical formulation. In a graphlcal degcrlption one might say that the real vegetation canopy with it. finlte number of discrete lenves and stems hata heel. replaced by a gag-like medlum whose ridlitlye properties are equivalent co the real simopy In a volume-nveraged sense.

llowever. certiof ratlative effects of llitural canoples the are hased on the discrete nature of Its components are no longer deacrlbed by the RT fulination and cannot be obtalnod by iny what qoever sophlaticaled and/or rlgorous yolullin iechinlife. Such effects are for exilaple llinge that ate dise to leaf yhupe and the mithill yhadlup or climplag of leaves. Thl a diffeuley and Intrligle $1 \mathrm{Imltat}$ on of the ht formulat lian of

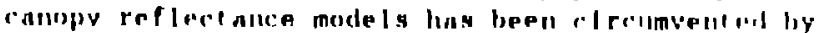

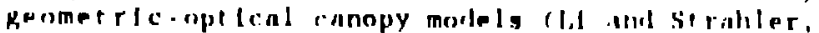

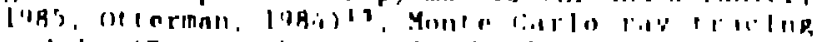

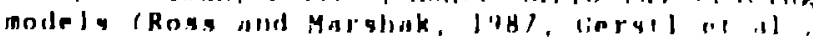

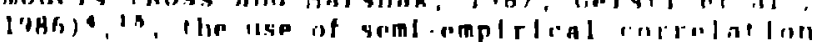

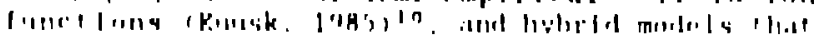

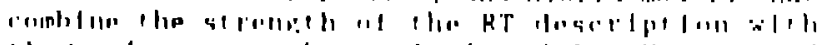

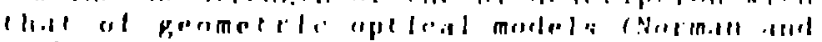
Hollos, johld.

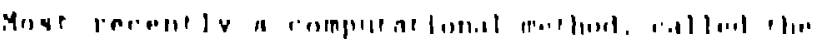

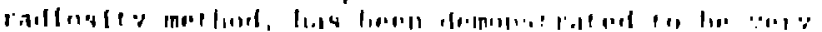

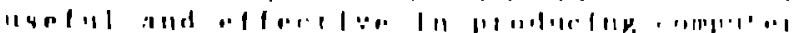

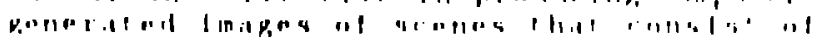


reflecting surfaces, like a room filled with turniture and other objects under arbitrary ll lumination condiclons (Greenbers. 1949) ${ }^{7}$. The radiosity method, which is the basts for such compular graphics. Is also based on a radiation billine equation. However, In contrast to the RT equation, the radiostev equation balances Incoming and nutgolng radiation fluxes on discretc surface elements and has the form

$$
B_{1}=E_{1}+\rho_{1} \sum F_{1 j} B_{j} \text {. }
$$

thici b. Is the radiosicy on surface element 1 , definrdis the total radiation flux density leaving that surface $\left(e . g\right.$. In $\mathrm{W} / \mathrm{cm}^{2}$ or $\left.\mathrm{J} / \mathrm{cm}^{2}\right)$. $\mathrm{E}_{\text {, }}$ is the surface emission, $\rho$ the reflection coefficient and $F$ the form factor or "view factor" whlch specifles the fraction of radiant flux leaving another surface $j$ that reaches the surface 1. Thus, the radiosity equation (2) also staics a tigornus energy balance requlting the tolal radiation flux leaving any surface element 1 to be equal to the sum of its emitted and reflected slux orlginating from all other surfaces. This descrlption of a radiatlve energy equilibrlum has originated in thermal engineering to describe the transmission of radiant heat between surfaces of different temperatures (e. Hott(l and Sarof $1 m, 1967)^{8}$ and has been Introluced to compuice graphles ty Goral et al, (1984) $)^{\circ}$ as a new rocedure for realistle Image synthests. Wlth the rapla development of advanced computer graplics hardware and software the radiosity method has become a cornerstone for modern $1 \mathrm{mage}$ synticas (Greenberg, 1989, Cohen et al, $1788)^{2} . ?$

Wo demonstrate that with approprlate modlfleatlons to the governing radiostey equationg it ls posstble to apply this methudology successfully to the comput at ion of reflectance distrlbutlons from realistic j-dimensional surfaces, such as a veriention canopy that la composed of many discrete reflecting surfaces (leaves and stems). Morecivel, since fintre surface elements are rollstared as the basp undts of the computat lor:, the radiosliy method is capable of descrlblug the radiat ive eflects due to the discrete nature of lades and stems (shadlng, clumplup etc.). The solar lriadlance on each Indluldual leaf can also br computrel. Such data Is of cructal Importaner I1) nnilvalng. photosynthesis, nutelent and other hlochenles' transport mechanleme wlthlu reallsile pldils. As lnig, ns the plant archltecture call be sat lefactorlly descrlled by n set of discrete sulf nces with glven orlentatlon, the radlost erjuntou wlll provide a volunble complement in the

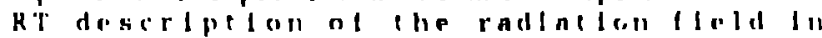
vepolation canoples and on thelr boundarlos.

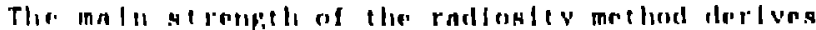
llom lhe fart lhat lanves are tereted as ladleldual sutfaces that reflect and lrallsmlt

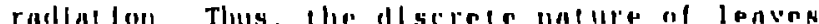

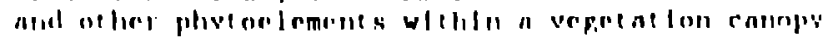

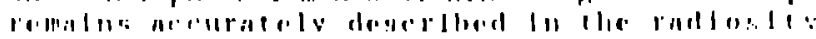

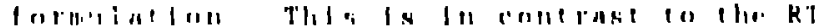

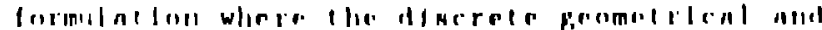

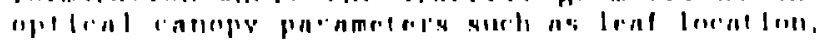

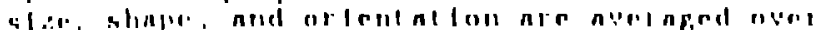

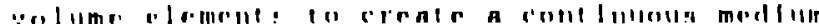

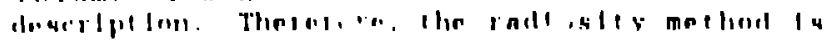

expected to provide a valuable complement to the RT formulation in canopy reflectance modeling. becauge it allows the analysis of radiative effects due to the discrete nature of leaves and stems and the Ir heterogeneous distributions. Exumples of such effects are the mutual shading and clustering of leaves which can produce varlations in BRDF values of up to factors of two as shown by field measurements on natural cannples. The radiosity method is parcicularly sulted to model the angular reflectance slgnatures of vegetation canoples, such as the retroreflectance peak, also called the canopy hot spot. cf. Borel et al. (1989)', Gerstl (1488)s

\section{REFERENCES}

[1] C.C. Borel, B.J. Powers, ald S.A.h. Cierstl "Modelling of the Angular Reflectance nf al Artificlal Canopy near the Retroreflection Peak In the Optical Reglme." IGARSS 'By Proceedings, July 1989.

(2) M.F. Cohen, S.E. Chen, J.R. Wallace, and D Greenberg, "A Progressive Refinement Arproach to Fast padios 1 ty Image Givicition," SIGGRAPH Procecdlngs. 22(4), p 75, 1988

[3] S.A.W. Geracl and A. Zardeck1. "Counled Atmosphere/Canopy Model for Remote Senstrig, of Plant Reflectance fiatures," Appl. Opt, 24. PP. $94.103,1985$

(4) S.A.H. Gerst 1, C. S1mmer and B, I. Powurs, "Thic Cannpy Hot-Spot as Crop Irlentlfiel." Proc. Int, Symp. on Rerote Sensling for Resources Development and Enilronmental Management, Enschede. The Netherlands. M.C.J. Damen et al. (Eds.) pp. 261-263, 1986

(5) S.A.W. Cierstl. "The Angular Reflectance Slgnature of the Cnnopy llot Spot In tho Optlcal Reglma, "Proc hell Jue call on Spectral Signatures of oblecte lil kemole Selising. Aussola, France, Fis report $S P-28 /$. pr. $179-132,1988$

16) C. Goral, K, E, Torrance, D. Grectiberg, and B. Batcalle, "Modelling the Interaction of LI phe Between DIf fuse Surfacen, "SIcicirari Prociedlups, 18(3), 1984.

I/I D.f. Gi.enberg, "I.Igh" Koflectlon Muclols for cinmputer ciraphles," sciltencit. 2ia, pl, IbG. 113. 1987.

iB! H.G. Hollel and A.F. Sninflan. "Knalintlvo

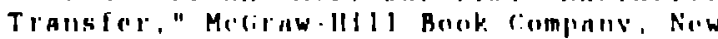
fork, Now Yomk. Jut,

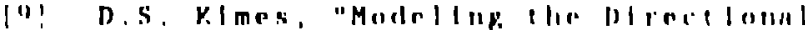

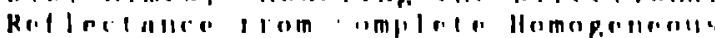

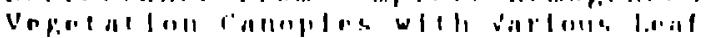
(11. I Aln. AL, IN ' ', 'J', IHH.

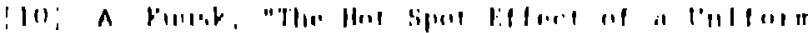

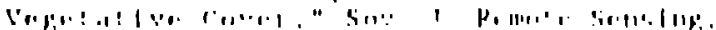

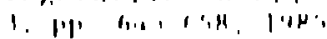


[11] J, V. Marconchlk and D.J. Diner. "ThreeDimensionil Ralliative Transfer lising a Fourier-Trinstorm Matrix-Operator Mt:hod." J. Quant. Spec. Rad. Transf. 3i. p. 133, 1285.

[12! J.M. Norman and J.M. Welles, "Radlatlye Transfer in an Array of Canoples," Agron. J. . 25. Pp. $481-488,1983$

[13] J. Otterman, "Albedo of a Forest Modeled as a Plane with Dense Protruslons," J. Climate and Appl. Meteor, 23, Pp. 297-307, 1934.

lit: J. Ross. "The Radiation Reglme and Archltecture of Plant Stands," Dr. W. Junk Publ.. The Hague. 1981.

[15] J.K. Ross and A.L. Marshak, "Culculation of the Canopy Bidirectlonal Peflectance Using the Monte Carlo Method," Remote Seng. En:1ron. 24, PP. 213-225, 1987

[16] J,K. Shultis and R.B. Mynenl. "Radlatlve Transfer In Vegetation Canoples with Anlsotrople Scattering." J. Quant. Spec. and Rad, Trintisfer., 1988 